\title{
Correspondance
}

\section{Lead poisoning in children}

$\mathrm{T}$ he case history of lead poisoning presented by Pascal Lavoie and Benoit Bailey ${ }^{1}$ illustrates the surreal state of political responses to this issue in Canada today.

The authors assert that lead poisoning is now rare in Canada, ${ }^{1}$ but there are almost no current data on this problem. The last national pediatric blood lead survey of Canadian children took place in $1978,{ }^{2}$ and the few regional surveys conducted in Canada since then have revealed elevated blood lead levels in $2 \%$ to $11 \%$ of children tested. ${ }^{3,4}$ Lack of reporting of a problem does not prove its absence.

While paint is the primary source of lead exposure in Canada, ${ }^{5}$ there are other significant sources, including household drinking water (via lead plumbing fixtures), contaminated soil, maternal stores, consumer products and game contaminated with lead shot.

Today, in 2004, there is still no Canadian standard for "safe" interior lead dust levels in housing. At the 1997 G-8 Summit in Denver, Canada was an official signatory to the Declaration on Children's Environmental Health, which called for further reductions in maternal and child exposure to lead. Now, 7 years later, Health Canada's Consumer Product Safety group is finally developing a lead risk reduction strategy to address the hazards of lead in consumer products. ${ }^{6}$ However, scant attention has been paid to lead exposure through housing.

In 1994 the Health Canada report on blood lead intervention levels and strategies" recommended that "investigations be carried out to assess the existence and extent of undue exposure to lead in paint in dwellings in Canadian cities." Ten years later this recommendation has still not been followed.

We need to do more to protect future generations of Canadians than simply identify lead-poisoned children on a case-by-case basis. We need a national system for collecting, monitoring and reporting data on pediatric lead poisoning, and then we must act to eliminate the problem.

\section{Warren Bell}

President

Canadian Association of Physicians

for the Environment

Toronto, Ont.

\section{Kelly O'Grady}

President

Lead Environmental Awareness and Detection

Pembroke, Ont.

\section{References}

1. Lavoie PM, Bailey B. Lead poisoning from "lead-free" paint. CMA7 2004;170(6):956.

2. Canada bealth survey (1978-79). Ottawa: Statistics Canada; 1982.

3. Lead screening report Eastside Community, Port Colbrone April-fune, 2001. Thorold (ON): Regional Niagara Public Health Department; 2001.

4. A study of blood lead levels in children living in Saint John, New Brunswick. Saint John: New Brunswick Health and Community Services; 1993.

5. Rasmussen PE, Subramanian KS, Jessiman BJ. A multi-level profile of housedust in relation to exterior dust and soils in the city of Ottawa, Canada. Sci Total Environ 2001;267:125-40.

6. Healthy Environments and Consumer Safety Branch, Consumer Product Safety Bureau. Lead risk reduction strategy [draft]. Ottawa: Health Canada; 2002 Feb. Available: www.hc-sc.gc.ca /hecs-sesc/cps/lrrs.htm (accessed 2004 July 27).

7. Federal-Provincial Committee on Environmental and Occupational Health. Update of evidence for low-level effects of lead and blood lead intervention levels and strategies - final report of the working group. Ottawa: Health Canada, Environmental Health Directorate; 1994.

DOI:10.1503/cmaj.1040573

$\mathrm{P}$ ascal Lavoie and Benoit Bailey ${ }^{1}$ report that paint scrapings from the home of a young child with elevated blood lead levels were less than $0.5 \%$ dry weight, which is considered "leadfree" in Canada. However, far from being "lead-free," $0.5 \%$ lead is the same as 5000 parts per million, plenty high enough to elevate a child's blood lead level. The "lead-free" standard in the United States is 600 parts per million, established by regulation in the late 1970s. ${ }^{2}$ Canadian paint manufacturers have generally followed the US standard, but as of March 2004 Canada had yet to pass regulations, ${ }^{3}$ proposed in 2003 , that would see the adoption of the standard that the United States put in place over 25 years ago. ${ }^{4}$

Another useful comparison is the residential soil replacement guideline in Ontario. Soil with a lead concentration over 200 parts per million is considered unsafe for children because it can contribute to elevated blood lead levels. ${ }^{5}$ It is certainly advisable to look for other sources of lead in a child's environment, but when there is clear evidence of pica, you don't need to look further than the paint in a home built in the 1950s. Indeed, houses built until the late 1970s should be similarly suspect. Nor can we rely on the effectiveness of standards established under Canada's antiquated Hazardous Products Act. ${ }^{6}$

The global dimensions of the problems of environmental lead exposure are summarized by Tong and associates.? Although the problem is even worse in developing countries, lead remains a concern worldwide. The long history of lead use in a wide variety of applications has created a vast reservoir (including paint), and awareness and preventive action are needed to minimize exposure.

\section{Kathleen Cooper \\ Senior Researcher \\ Canadian Environmental Law \\ Association \\ Toronto, Ont.}

\section{References}

1. Lavoie PM, Bailey B. Lead poisoning from "lead-free" paint. CMAf 2004;170(6):956.

2. Ban of lead-containing paint and certain consumer products, 16 C.F.R. 1303 (1977) [US regulation]. Available: www.gpoaccess.gov/cfr/index.html (accessed 2004 Apr 20).

3. Surface coating materials regulations (Regulatory Impact Analysis Statement). Can Gaz 2003; 137(24):1875-87. Available: canadagazette.gc.ca /partI/2003/20030614/pdf/g1-13724.pdf (accessed 2004 July 30).

4. Cooper K, Vanderlinden L, McClenaghan T, Keenan K, Khatter K, Muldoon P, et al. Case study \#1: Standard setting for lead - the cautionary tale. In: Environmental standard setting and children's bealth. Toronto: Canadian Environmental Law Association and Ontario College of Family Physicians Environmental Health Committee; 2000. p. 226-83. Available: www .cela.ca/coreprograms/detail.shtml? $\mathrm{x}=1326$ (accessed 2004 Jul 18).

5. Appendix 1: Summary of approvals information In: Guideline for use at contaminated sites in Ontario. Toronto: Ontario Ministry of Environment; rev. 1998 Sep. Available: www.ene.gov.on.ca/envision /gp/3161e01_appendix.pdf (accessed 2004 Apr 20). 